\title{
KEWARISAN ANAK ANGKAT DALAM PERSPEKTIF HUKUM ISLÂM
}

\author{
Abd. Ghoffar \\ (Dekan Fakultas Agama Islam UIM Pamekasan dan Ketua PCNU \\ Pamekasan, Alumni Program S2 Unisma Malang Konsentrasi \\ Studi Hukum Islam )
}

\begin{abstract}
Abstrak:
Hukum Islâm sebagai sebuah dimensi telah memberikan ornamen yang mampu menjawab tantangan zaman, termasuk di dalamnya problematik pemindahan kekayaan berupa kewarisan kepada anak angkat. Hukum Islâm dengan tegas menyatakan bahwa anak angkat tidak berhak menerima harta warisan. Hal ini dikarenakan Islâm memandang bahwa anak angkat tidak memiliki ikatan nasab keturunan dengan orang tua angkatnya. Karenanya, Islâm melarang pemberian hak istimewa kepada anak angkat tersebut, seperti persambungan garis keturunan anak angkat kepada orang tua angkatnya. Demikian pula, Islâm melarang penghapusan kemahraman anak angkat laki-laki dengan ibu angkat dan saudara perempuan tirinya. Namun demikian, Islam masih memberikan solusi-tawaran berupa hibah, wasiat, atau pun wasiat wâjibah. Mereka merupakan solusi hukum menuju kesejahteraan umat manusia, terutama bagi mereka yang diberikan keterbatasan berupa tidak bisa memiliki keturunan, sehingga ia tetap bisa berderma untuk orang lain khususnya kepada anak angkatnya.
\end{abstract}

Kata Kunci:

kewarisan, anak angkat, hibah, wasiat, dan wasiat wâjibah.

\section{Pendahuluan}

Islâm memelihara hubungan nasab dan melarang suami mengingkari nasab anak yang dilahirkan istrinya dalam keadaan hubungan perkawinan itu masih berlangsung. Sejalan dengan ketentuan tersebut Islâm pun tidak membenarkan seseorang mengangkat anak orang lain dengan jalan memutuskan hubungan nasab dengan orang tuanya, kemudian memindahkan hubungannya 
dengan bapak angkatnya serta diberi hak-hak yang sama dengan anak kandungnya.

Sejarah membuktikan, ketika Islâm mulai diajarkan Nabî Muhammad saw., kebiasaan mengangkat anak sudah meluas di kalangan bangsa Arab. Misalnya, Khudzayfah mengambil anak Sahij dan al-Khattâb mengambil anak Amr bin Rabî’ah. Nabî Muhammad sendiri sebelum diangkat sebagai Rasûl Allâh juga mengangkat seorang anak beranama Zayd bin Hâritsah. Sewaktu kecil, ia pernah menjadi budak rampasan perang dalam salah satu peperangan yang terjadi di kalangan bangsa Arab pada zaman Jâhiliyah. Pada perkembangan selanjutnya, Zayd menjadi budak Khadîjah. Sewaktu Khadîjah dinikahi oleh Muhammad, ia diberikan kepada suaminya tersebut. Hal ini berlangsung sampai Muhammad diangkat menjadi Nabî. ${ }^{1}$

Pada waktu orang tua kandung dan paman Zayd berkunjung kepada Nabî, sesungguhnya Nabî telah memberi kebebasan kepada Zayd, apakah ia ingin kembali kepada keluarganya atau tetap tinggal bersama dirinya. Namun, ia memilih tinggal bersama Nabî. Kemudian, Nabî saw. memerdekakannya dengan mempersaksikan kepada orang banyak bahwa Zayd menjadi anak angkatnya, sehingga sejak saat itu ia dikenal dengan nama Zayd bin Muhammad.

Persoalan yang muncul kemudian adalah bagaimana sesungguhnya pandangan Islâm terhadap keberadaan atau status anak angkat yang menjadi kebiasaan bangsa Arab sejak jaman jâhiliyah itu. Dalam kaitan ini, Islâm memandang bahwa anak angkat tidak memiliki ikatan nasab keturunan dengan orang tua angkatnya. Karenanya, Islâm melarang pemberian hak istimewa kepada anak angkat tersebut, seperti persambungan garis keturunan anak angkat kepada orang tua angkatnya. Demikian pula, Islâm melarang penghapusan kemahraman anak angkat laki-laki dengan ibu angkat dan saudara perempuan tirinya.

Selain itu, hak anak angkat untuk mewarisi harta peninggalan bapak angkatnya sering menghalangi keluarga asli dari bapak angkatnya, yang selanjutnya mengakibatkan timbulnya kedengkian

1 'Alî al-Sâyis, Tafsîr Âyât al-Ahkkâm, Juz 4 (Damaskus: Dâr al Fikr, t.th.), hlm. 7. 
dari keluarga yang sebenarnya terhadap anak angkat pendatang itu. Oleh kerena itu, Islâm secara tegas membatalkan kebiasaan yang memandang anak angkat sebagai anak kandung. Anak angkat hanyalah sekedar pengakuan yang tidak sesuai dengan kenyataan. Pengakuan atas anak angkat tidak dapat mengubah kenyataan bahwa anak angkat dilahirkan oleh ibu kandungnya. Karenanya, Islâm menganjurkan agar anak angkat itu tetap memakai nama bapaknya sendiri. Tetapi, apabila terdapat sebuah kasus di mana bapaknya tidak diketahui, Islâm menganjurkan untuk memanggilnya sebagai saudara seagama dan mawlâ. ${ }^{2}$ Karenanya, melepaskan hubungan nasab dengan ibu dan ayah kandungnya sama sekali tidak dibenarkan karena, di satu sisi, bertentangan dengan keadaan yang sebenarnya dan, di sisi lain, bertentangan dengan pembawaan watak kodrati manusia.

\section{Anak Angkat: Makna, Dasar Hukum, dan Status}

Anak angkat (adopsi) dalam hukum Islâm dikenal dengan istilah tabannî atau da' orang yang dipanggil anak walaupun kenyataannya ia bukan anaknya. ${ }^{2}$ Sedangkan Mahmûd Syaltût membedakan makna anak angkat ke dalam dua bagian. Pertama, seseorang mengambil anak orang lain untuk diperlakukan seperti anak kandung sendiri dalam rangka memberi kasih sayang, nafkah, pendidikan, dan keperluan lainnya walaupun secara hukum anak itu bukan anaknya. Kedua, memasukkan anak yang diketahuinya sebagai orang lain, yakni tidak ada pertalian nasab kepada dirinya sebagai anak sah, ke dalam keluarganya, sehingga ia mempunyai hak dan ketentuan hukum sebagai anak. ${ }^{3}$

Dengan demikian, anak angkat (adopsi) dapat dimaknai sebagai mengambil anak orang lain dengan memperlakukannya

\footnotetext{
2 Al-Qur'ân, al-Ahzâb (8): 4-5. Mawlâ dalam konteks ini adalah budak yang telah dimerdekakan atau seseorang yang dijadikan anak angkat. Contohnya, seorang bernama Salim anak angkat Muzayfah, maka ia disebut dengan "Salim mawlâ Muzayfah"

2 al-Sâyis, Tafsîr, hlm., 7 .

${ }^{3}$ Mahmûd Syalțût, al-Fatawâ (Damaskus: Dâr al-Qolam, t.t,), hlm. 292.
} 
sebagai anaknya sendiri dalam hal pemeliharaan, pengasuhan, dan pendidikannya. Hanya saja pengangkatan anak ini dibedakan ke dalam dua tipe, yaitu: Pertama, pemberian status anak angkat sama persis dengan anak sah dalam segala hak dan kewajibannya, seperti hak menerima nafkah, pendidikan dan bahkan kewarisan, sehingga saling mewaris antara anak angkat dan orang tua angkatnya. Kedua, pemberian status anak angkat bukan sebagai anak sah, namun karena rasa tanggung jawab sosial, ia dipelihara dan dididik dengan penuh kasih sayang.

Dasar hukum pengangkatan anak adalah berdasarkan alQur'ân surat al-Ahzâb (33) ayat 4 dan 5 sebagai berikut:

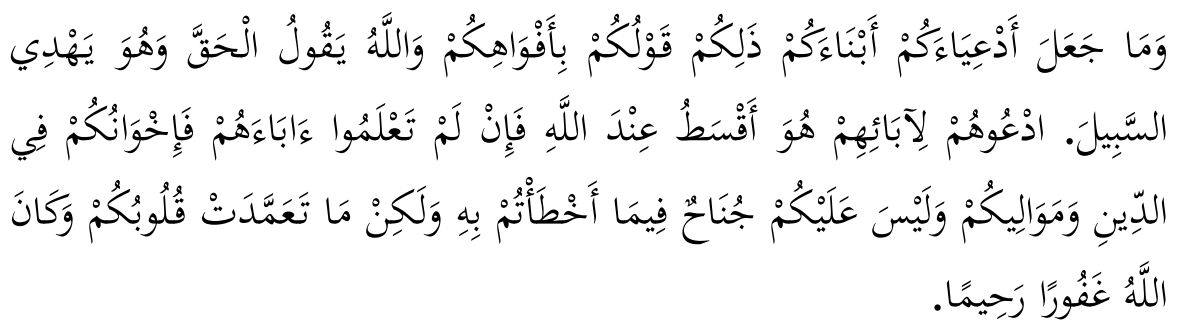

Dia tidak menjadikan anak-anak angkatmu sebagai anak kandungmu (sendiri). Yang demikian itu hanyalah perkataanmu di mulutmu saja. Dan Allâh mengatakan yang sebenarnya dan Dia menunjukkan jalan (yang benar). Panggillah mereka (anak-anak angkat itu) dengan (memakai) nama bapak-bapak mereka; itulah yang lebih adil pada sisi Allâh, dan jika kamu tidak mengetahui bapak-bapak mereka, maka (panggillah mereka sebagai) saudara-saudaramu seagama dan maulamaulamu. Dan tidak ada dosa atasmu terhadap apa yang kamu khilaf padanya, tetapi (yang ada dosanya) apa yang disengaja oleh hatimu. Dan adalah Allâh Maha Pengampun lagi Maha Penyayang. ${ }^{4}$

Di samping, terdapat beberapa Hadîts yang menjadi dasar hukum pengangkatan anak, yaitu:

1. Hadîts riwayat Ibnu Umar r.a.

4 Departemen Agama RI., Al-Qur'an dan Terjemahnya (Jakarta: Proyek Pengadaan Kitab Suci al-Qur'an, 1977/1978), hlm. 666-667. 


$$
\begin{aligned}
& \text { عن ابن عمر رضي الله عنهما انه قال إن زيد ابن حارثة مولى رسول الله } \\
& \text { صلى الله عليه وسلم. ما كنا ندعوه الا زيد بن محمد حتى نزل القران, } \\
& \text { ادعوهم لابأهم هو اقسط عند الله. فقال النبي صلى الله عليه وسلم. انت } \\
& \text { زيد ابن حارثة (اخرجه البخارى) }
\end{aligned}
$$

Dari Umar ra., ia berkata: Sesungguhnya Zayd bin Hâritsah adalah budak yang dimerdekakan Rasûlullâh saw., dan kami memanggilnya dengan Zayd bin Muhammad, sehingga turun ayat "Panggilah mereka dengan nama ayah (kandung) mereka, itulah yang lebih adil di sisi Allâh swt". Lalu Nabî saw. berkata: Engkau adalah Zayd bin Hâritsah (HR. Bukhârî)

2. Hadîts riwayat Abî Dzarr ra:

$$
\begin{aligned}
& \text { عن ابى ذرّ رضي الله عنه انه سمع رسول الله صلى الله عليه وسلم يقول: } \\
& \text { ليس لرجل ادّعى لغير ابيه وهو يعلم الاكفر. (رواه الشيخان) } 7
\end{aligned}
$$

Dari Abî Dzar r.a: Sesungguhnya ia mendengar Rasûlullâh bersabda:"Tidak seorangpun yang mengakui (mebangsakan diri kepada bukan ayahnya, sedangkan ia tahu bahwa ia bukan ayahnya, melainkan ia telah kafir" (HR. Bukhârî dan Muslim)

Dengan mempelajari makna anak angkat dan dasar hukumnya sebagaimana penjelasan di atas, dapat diketahui bahwa status hukum anak (adopsi) adalah sebagai berikut: Pertama, mengangkat anak (adopsi) dengan pengertian anak tersebut putus hubungan keturunan (nasab) dengan ayah dan ibu kandungnya adalah bertentangan dengan syarî́at Islâm (dilarang). Kedua, mengangkat anak (adopsi) dengan tidak mengubah status nasab dan dilakukan atas rasa tanggung jawab sosial untuk memelihara, mengasih, dan mendidiknya dengan penuh kasih sayang adalah

\footnotetext{
${ }^{6}$ Al-Sâyis, Tafsîr, hlm. 263.

7 Abû Abdillâh, Shahîh al-Bukhârî, Juz 7 (Beirut: Dâr al- Mathabi al-Sya'bî, t.th.), hlm. 135.
} 
perbuatan terpuji dan termasuk amal shaleh yang dianjurkan oleh agama. Ketiga, anak angkat menurut hukum Islâm tidak diberi status hukum seperti anak sah. Keempat, memberi status hukum anak angkat sama seperti anak sah adalah perbuatan dosa besar. ${ }^{3}$

Salah satu point di atas, yang perlu mendapatkan penekanan, adalah bahwa mengangkat anak tanpa memberi status sebagai anak sah, tetapi karena tanggung jawab sosial untuk memelihara, mengasuh, dan mendidik dengan penuh kasih sayang adalah perbuatan terpuji. Untuk hal tersebut, perlu diperhatikan aspek-aspek sebagai berikut:

a. Aspek Pengertian

Dalam Islâm, tidak dikenal pengangkatan anak yang diberi status anak kandung. Mengangkat anak yang didorong oleh tanggung jawab sosial dan dilakukan dengan penuh kasih sayang dan tidak diberi status anak kandung tidak dilarang. ${ }^{9}$

b. Aspek misi keadilan sosial

Dari aspek misi keadilan sosial, pengangkatan anak dengan cara yang benar adalah membuka kesempatan kepada si kaya untuk beramal melalui wasiat dan hibah kepada anak angkatnya untuk menutupi kebutuhannya dihari esok. Perbuatan ini merupakan pancaran kecintaan kepada Allâh sebagai suatu misi Islâm yang sangat penting dalam usaha menegakkan keadilan sosial.

c. Aspek budi pekerti

Ditinjau dari aspek ini, orang yang mengangkat anak dengan cara yang benar berarti menerapkan rasa penuh kasih sayang sesama muslimnya, dan hal tersebut termasuk Akhlaq alKarimah.

d. Aspek pengamalan ajaran Islâm

Orang yang mengangkat anak dengan cara yang benar tersebut, berarti mengamalkan bagian ajaran Islâm yang memerintahkan untuk saling tolong menolong sesamanya.

\footnotetext{
${ }^{3}$ Muhammad Alî al-Shabûnî, Tafsîr Âyât al-Ahkâm, Juz 2 (Makkah : Dâr al-Fikr, t.th,), hlm. 263

${ }^{9}$ Al-Alûsî, Tafsîr Rûh al-Ma'âni , Juz 21 (Beirut : Dâr al-Fikr, t.th), hlm. 149.
} 
Bagi yang mampu harus membantu yang tidak mampu dan juga berkewajiban memelihara anak-anak yang terlantar.

\section{Kewarisan Anak Angkat}

Sebagaimana dijelaskan di muka bahwa pada zaman jâhiliyah dan permulaan Islâm, anak angkat dipanggil sebagai putra dari orang tua angkatnya dan di antara mereka terjadi saling waris-mewarisi. Bahkan, Rasulullah saw., sebelum turunnya surat al-Ahzab (33) ayat 4, pernah menegaskan bahwa Zayd itu adalah putranya, dalam mana keduanya saling mewarisi. Hal ini ditegaskan oleh Muhammad 'Alî al-Shabûnî berikut ini.

$$
\begin{aligned}
& \text {... فخرج رسول الله صلى الله عليه وسلم الى الناس وقال: اشهدوا أن زيدا ابن ارثه } \\
& \text { ويرثنى فطابت نفسى ابيه وعمه لما رواومكرمة زيد عليه صلى الله عليه وسلم قلم يزل } \\
& \text { فى الجاهلية يدعى زيد بن محمد حتى نزل القران الكريم: “أدعوهم لابائهم هو } \\
& \text { أقسط عنه الله " فدعى زيد بن حارثه. } 7
\end{aligned}
$$

...Maka keluarlah Rasulullah saw. untuk menemui orang-orang manusia, seraya bersabda: "Saksikanlah bahwa Zayd anakku, saya mewarisinya dan ia mewarisiku. Akhirnya, tentu jiwa ayah dan paman Zayd setelah melihat betapa Zayd dimulyakan oleh Nabî saw. Setelah itu di masa jâhiliyah Zayd dipanggil bin Muhammad sampai turun alQur'an al-Karîm, " panggilah mereka denagn ayah-ayah kandung mereka, itu lebih adil di sisi Allâh swt. Kemudian Zayd dipanggil Zayd bin Hâritsah.

Dengan keterangan di atas dapat diketahui bahwa: Pertama, pada zaman jâhiliyah dan permulaan Islâm, anak angkat mempunyai status anak kandung, di mana antara anak angkat danorang tua angkatnya terjadi saling waris mewarisi. Kedua, setelah turunnya surat al-Ahzab (33) ayat 4-5, anak angkat tidak boleh diberi status anak kandung dan tidak boleh dipertalikan nasabnya dengan orang tua angkatnya, sehingga keduanya tidak bisa saling mewarisi.

7 Al-Shabûnî, Tafsîr, hlm. 264 
Hikmah dari pembatalan anak angkat model jâhiliyah ini, yakni dipanggil dengan nama orang tua angkatnya dan saling waris mewarisi, adalah bahwa pengangkatan anak secara jâhiliyah ini merupakan perbuatan bid'ah yang menjadi tradisi secara turuntemurun sehingga sulit untuk mengganti atau menghapusnya. Karena kebiasaan kaum jâhiliyah diwariskan secara turun temurun dari nenek moyangnya.

Pada zaman jahiliyah seseorang yang mengangkat anak dan mengatakan kepada anak angkatnya " "انت ابني ارثك وترثنى (Engkau anakku, saya mewarisimu dan engkau mewarisi saya). Setelah itu anak tersebut menjadi anak kandung dan berlaku hak-hak yang terkait dengannya, seperti tentang kewarisan, nikâh, thalâk, dan hubungan persemedanan. Kemudian Allâh swt. membatalkan tradisi ini, dan Nabî pun yang sebelumnya mengikuti tradisi jâhiliyah dengan menamakan Zayd bin Muhammad menjadi Zayd bin Hâritsah, di mana Hâritsah adalah ayah kandungnya sendiri. ${ }^{8}$

Dalam tradisi Islâm, menurut Syalthûth, salah satu bentuk pengangkatan anak ayng dijustifikasi Islâm adalah bahwa seorang mengambil anak orang lain untuk diperlakukan seperti anak kandung sendiri dalam hal pemberian kasih sayang, nafkah, pendidikan, dan keperluan lainnya. Namun, secara hukum anak itu bukanlah anaknya sendiri. Tabannî semacam ini adalah perbuatan yang pantas dikerjakan oleh orang-orang yang luas rezekinya, namun ia tidak dikaruniai anak. Mereka melihat bahwa pengambilan anak ini merupakan bentuk taqarrub (pendekatan diri) kepada Allâh swt. dengan mendidik anak fakir yang tidak dapat merasakan kasih sayang orang tuanya atau ayahnya dan tidak mampu membiayai pendidikan dan pengajaran anaknya. Tentu saja, perbuatan ini termasuk ke dalam amal yang dicintai syara' dan merupakan bentuk dakwah yang diberi pahala. Dalam kaitan ini, syara' sendiri membuka pintu bagi orang kaya untuk memberi wasiat kepada anak angkatnya dari sebagian tirkah-nya sebagai pemenuhan keperluan masa

8 Ibid. 
depannya sehingga ia merasakan ketenangan hidup dan jauh dari hidup sengsara. ${ }^{9}$

Dari keterangan di atas, dapat dipahami bahwa seorang anak yang diangkat karena motif sosial dan tidak diberi status anak kandung, orang tua angkatnya boleh orang tua angkatnya memberikan sebagian hartanya melalui wasiat. Kebolehan ini, antara lain, didasarkan pada makna wasiat itu sendiri, yakni pemilikan kepada orang lain yang disandarkan kepada setelah mati dengan jalan tabarru'sama saja, di mana pemilikan tersebut berbentuk benda atau manfaat. Dengan kriteria ini, wasiat berbeda dengan pemilikan langsung untuk benda seperti jual beli dan hibah, dan untuk manfaat seperti sewa menyewa. Dengan batasan setelah mati, wasiat berbeda pula dengan sewa bersyarat dengan waktu mendatang, seperti awal bulan depan, di samping juga berbeda dengan hibah, sebab wasiat pelaksanaannya setelah mati orang yang berwasiat, sedangkan hibah pelaksanaannya di masa hidup pemberi hibah. ${ }^{10}$

Selain itu, dalam wasiat ada ketentuan yang berbeda, di mana harta yang diwasiatkan tidak boleh lebih sepertiga, jika pemberi wasiat mempunyai ahli waris. Hal ini didasarkan atas ijmâ' ulamâ' dan hadits yang diriwayatkan oleh Abi Waqqash, di mana ketika ia hendak berwasiat, ia bertanya lebih dahulu kepada Rasûlullâh apakah dirinya akan mewasiatkan hartanya sebanyak 1/3 (sepertiga) atau $1 / 2$ (seperdua) dikarenakan ia hanya mempunyai satu orang anak perempuan, lalu Rasûlullâh saw. bersabda:

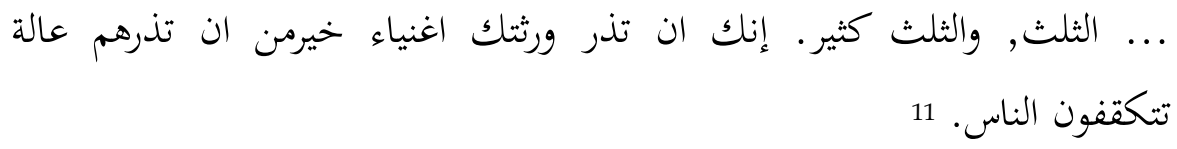

Sepertiga saja dan sepertiga itu banyak. Sesungguhnya, meninggalkan ahli warismu kaya lebih baik ketimbang meninggalkan mereka dalam keadaan miskin dan meminta-minta kepada orang lain.

${ }^{9}$ Syalthûth, Al-Fatâwâ, hlm. 292.

10 Wahbah al-Zuhaylî, Al-Fiqh al-Islâmî wa Adilatuhu, Juz 8, (Damaskus: Dâr al-Fikr, 1989), hlm. 7.

11 Al-Syawkânî, Irsyâd al-Fuhûl, Juz 6, (Beirut: Dâr al-Fikr, t.th.), hlm. 7. 
Apabila pemberi wasiat dengan adanya ahli waris memberi lebih dari $1 / 3$ (sepertiga), maka tangguhkan kelebihannya atas persetujuan ahli waris. Jika mereka setuju, maka kelebihan harta tersebut tetap menjadi wasiat. Persetujuan ahli waris ini dapat dilangsungkan apabila memenuhi dua syarat, yaitu: Pertama, persetuan tersebut dilaksanakan setelah matinya pemberi wasiat. Kedua, persetujuan itu dilakukan oleh ahli waris yang sudah akil baligh dan mengetahui jumlah harta yang diwasiatkan. Apabila sebagian ahli waris saja yang menyetujui, sedangkan lainnya tidak menyetujui, maka yang terjadi adalah hanya terbatas pada benda yang menjadi bagian yang menyetujuinya. Sedangkan bagian yang tidak menyetujuinya adalah batal.

Berbeda dengan hal di atas, apabila pemberi wasiat tidak punya ahli waris, maka, menurut Abû Hanîfah, kelebihan dari dari 1/3 (sepertiga) harta itu sah dan harus dilangsungkan sekalipun sampai menghabiskan seluruh harta. Tersebab kendala pelaksanaan wasiat lebih dari $1 / 3$ adalah terkait dengan ahli waris, jika ahli waris itu tidak ada, maka tidak seorang pun yang mempunyai hak dalam hal ini. Berbeda dengan pendapat ini, ulamâ' Mâlikiyah, $\underline{\text { Hanabilah, }}$ dan Syâfi'iyah berpendapat dalam hal wasiat lebih dari 1/3 dan tidak ada ahli warisnya, maka wasiat tersebut batal, karena kelebihan harta itu adalah harta milik orang-orang Islâm, dan oleh karena itu tidak ada yang dapat melaksanakan kehendak pemberi wasiat. ${ }^{12}$

Dari uraian tersebut di atas, dapat dikatakan bahwa peralihan hak milik dari seseorang kepada orang lain yang bukan ahli warisnya, dapat digunakan cara wasiat dengan ketentuanketentuan di atas. Di samping itu, ia juga bisa ditempuh dengan cara hibah, yakni pemberian langsung kepada anak angkat pada masa orang tua angkat masih hidup. Cara lainnya yang diatur oleh Islâm adalah melalui wasiat wâjibah, yaitu ketentuan yang menyatakan calon pewaris wajib membuat wasiat mengenai bagian tertentu harta peninggalannya. Dalam ketentuan Kompilasi Hukum Islâm (KHI), wasiat wâjibah itu diberikan kepada anak angkat. ${ }^{13}$

\footnotetext{
12 Al- Nawâwî, Al-Muhadzab, Juz 1 (Beirut : Dâr al-Fikr, t.th.), hlm. 450.

${ }_{13}$ Muhammad Daud Ali, Hukum Islam; Pengantar Ilmu Hukum dan Tata Hukum Islam di Indonesia (Jakarta: Raja Grafindo Persada,t.th.), hlm. 280.
} 


\section{Konstruk Ideal terhadap Peralihan Hak Milik kepada Anak Angkat.}

Terdapat dua tipe dalam pengangkatan anak, yaitu: Pertama, seorang anak diangkat dengan pengertian anak tersebut putus hubungan keturunan (nasab) dengan ayah dan ibu kandungnya. Dalam jenis ini ia diberi status sama dengan anak kandung dalam segala aspek hukumnya, termasuk juga dalam hal kewarisan. Adopsi tipe ini bertentangan dengan hukum Islâm. Kedua, pengangkatan anak dengan tidak mengubah status nasab. Ia dilakukan atas rasa tanggung jawab sosial untuk memelihara, mengasuh, dan mendidik mereka dengan penuh kasih sayang, seperti anak sendiri. Tindakan ini termasuk ke dalam perbuatan yang terpuji dan amal shâlih yang dianjurkan oleh Islâm.

Jenis pengangkatan anak yang kedua inilah yang bisa ditawarkan sebagai konstruk ideal, terutama berkenaan dengan peralihan hak milik dari orang tuanya kepada anak angkat tersebut. Orang tua angkat yang berkecukupan, baik yang mempunyai anak kandung maupun yang tidak mempunyai anak kandung, dengan didorong rasa kasih sayang yang tinggi dan berkeinginan untuk mengalihkan harta miliknya kepada anak angkatnya, seringkali melakukannya di luar ketentuan hukum Islâm. Agar perbuatan peralihan hak ini tersalurkan dengan benar dan menjadi perbuatan yang terpuji, maka berikut ini penulis tawarkan konstruk ideal, yaitu sebagai berikut:

1. Peralihan hak milik dari orang tua angkat kepada anak angkatnya melalui hibah.

Hibah dapat dimaknai sebagai pemberian suatu benda secara suka rela dan tanpa imbalan kepada orang lain yang masih hidup untuk dimiliki. ${ }^{14}$ Dengan kata lain, hibah merupakan akad yang memberi faedah mengalihkan pemilikan benda tanpa imbalan di waktu hidup karena taat pada Allâh swt. ${ }^{15}$

Dari pemaknaan di atas, penulis memberikan penjelasan sebagai berikut:

14 Ditbinbapera, Kompilasi Hukum Islam, Pasal 71 Ayat 9 (Jakarta: Ditbinbapera, 1991/1992), hlm. 34..

${ }_{15}$ Musthofa al-Khin, et.el., Al-fiqh al-Manhaji, Juz III, 101. 
a. Akad hibah berarti akad peralihan hak milik dari seseorang kepada orang lain tanpa adanya keharusan memberi imbalan kepada orang lain. Hal ini berbeda dengan jual beli, sebab dalam jual beli terdapat unsur imbalan dalam peralihan pemilikan suatu barang.

b. Dengan ada batasan peralihan pemilikan di masa hidup, maka jelas hibah berbeda dengan wasiat, sebab sekali pun wasiat termasuk peralihan pemilikan tanpa imbalan, namun yang terakhir ini dilakukan setelah mati.

c. Dengan batasan atas jalan perbuatan sunnah (tathawwu'), hibah berbeda dengan zakat, karena zakat merupakan peralihan pemilikan yang didasarkan pada kewajiban sebagai seorang Muslim.

Dengan hibah ini, Islâm mencanangkan azaz saling cinta mencintai antar sesama, yang kaya memberi kepada yang miskin dan yang miskin dipenuhi kebutuhannya oleh yang kaya, sehingga terbentuk masyarakat penuh kasih sayang antara sesamanya. Dalam kaitannya dengan peralihan hak milik dari orang tua angkat kepada anak angkatnya, maka hibah ini sangat cocok karena antara keduanya sudah terjadi suasana saling mencintai. Dengan ini maka terealisasi saling bantu membantu dalam kebaikan dan taqwâ.

Allâh berfirman dalam surat al-Maidah (5) ayat 2, sebagai berikut:

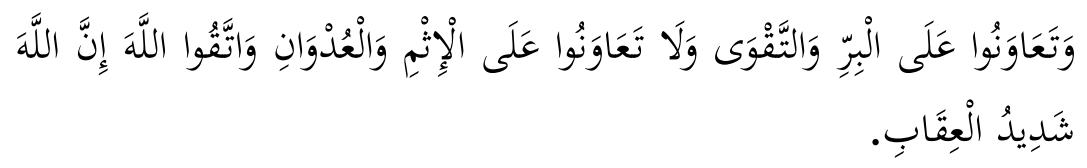

Dan tolong-menolonglah kamu dalam (mengerjakan) kebajikan dan takwa, dan jangan tolong-menolong dalam berbuat dosa dan pelanggaran. Dan bertakwalah kamu kepada Allah, sesungguhnya Allah amat berat siksa-Nya. ${ }^{16}$

2. Peralihan hak milik dari orang tua angkat kepada anak angkatnya dengan cara wasiat.

${ }^{16}$ Depag, Al-Qur'an dan Terjemahnya, hlm. 155. 
Dalam konteks tersebut, wasiat dimaknakan sebagai pengalihan pemilikan sesuatu oleh seseorang yang disandarkan setelah matinya dengan jalan tabarru' (berbuat baik) sama saja sesuatu tersebut berupa benda atau manfaat. ${ }^{18}$

Peralihan dengan cara wasiat ini sesuai dengan saran atau himbauan Mahmûd Syalthûth dalam kitabnya al-Fatâwâ sebagai kutipan berikut ini.

Sesungguhnya syarî́at Islâm membuka pintu wasiat bagi orang kaya dalam hal anak angkat yang bermotif rasional ini, agar ia benar-benar berwasiat sebagian dari tirkah-nya guna memenuhi kebutaan anak angkat tersebut mendapat masa depan sehingga kehidupannya tidak goncang dan tidak mengalami kesulitan hidup. 17

Dalam wasiat ini, terdapat beberapa ketentuan penting, yaitu;

a. Pada dasarnya wasiat tidak boleh lebih dari $1 / 3$ (sepertiga) tirkah. Hal ini didasarkan kepada hadits riwayat Sa' ad bin Abi Waqqas, sebagaimana disebutkan di atas.

b. Apabila wasiat itu lebih dari 1/3 (sepertiga) tirkah, maka kelebihannya tersebut harus ditinggalkan atas persetujuan ahli waris. Jika disetujui, maka wasiat tersebut terjadi, dan apabila tidak disetujui, maka untuk kelebihan dari $1 / 3$ (sepertiga) tirkah tersebut tidak jadi. Persetujuan ahli waris seperti yang dimaksud di atas, baru bisa diterima apabila memenuhi dua syarat: Pertama, persetujuan langsung setelah matinya pemberi wasiat. Kedua, ahli waris yang menyelenggarakan persetujuannya harus terdiri dari orang yang akil baliqh yang tidak dibawah pengampunan serta tahu jumlah dari benda yang diwasiatkan.

c. Adapun wasiat yang lebih dari 1/3 (sepertiga) tirkah dalam hal ahli warisnya tidak ada sama sekali, maka ketentuan hukumnya dipersilisihkan oleh para ulamâ' fiqh sebagai berikut:

\footnotetext{
18 Zuhaili, al-Figh al-Islâmi, hlm. 8.
}

17 Syalthûth, Al-Fatâwâ, hlm. 293. 
Abd. Ghoffar

d. Menurut ulamâ' Hanafiyah, wasiat lebih dari 1/3 (sepertiga) tersebut, sah dan bisa langsung dilaksanakan sekali pun sampai menghabiskan seluruh tirkahnya, dengan alasan kendala pelaksanaan wasiat lebih dari 1/3 (sepertiga) tirkah itu adalah adanya ahli waris, dan tidak boleh dilaksanakan tanpa kerelaaanya. Oleh karena itu, jika ahli waris tersebut tidak ada, maka tidak ada hak bagi siapa pun untuk menghalangi pelaksanaan wasiat tersebut. Sedangkan menurut ulamâ' Mâlikiyah, Hanabilah dan Syâfi'âyah, wasiat yang lebih dari $1 / 3$ sepertiga dalam hal ahli waris tidak ada, maka untuk kelebihannya adalah batal, karena sisa harta peninggalan si pemberi wasiat tersebut merupakan milik semua kaum Muslim, sehingga ia tidak bisa dilaksanakan hanya oleh sebagian Muslim saja. Karenanya, orang tua angkat yang ingin mengalihkan hak miliknya kepada anak angkat bisa melalui jalur wasiat dengan segala ketentuan-ketentuannya.

3. Peralihan hak milik dari orang tua angkat kepada anak angkatnya melalui wasiat wâjibah.

Muhammad Daud Ali memaknai wasiat wâjibah sebagai suatu ketentuan yang menyatakan calon pewaris wajib membuat wasiat mengenai bagian tertentu harta peninggalannya. ${ }^{20}$ Dengan kata lain, wasiat wâjibah merupakan suatu cara pengalihan hak milik dari orang tua angkat kepada anak angkatnya.

Ketentuan wasiat wâjibah bagi anak angkat ini dapat diketahui dari pasal 209 ayat (2) Kompilasi Hukum Islâm (KHI), yaitu "terhadap anak angkat yang tidak menerima wasiat diberi wasiat wâjibah sebanyak-banyaknya $1 / 3$ dari harta warisan orang tua angkatnya. ${ }^{19}$

Ketentuan wasiat wâjibah dalam Kompilasi Hukum Islâm tersebut dapat diterima dengan alasan sebagai berikut:

a. Pemberian wasiat wâjibah pada anak angkat bermotif sosial keagamaan merupakan terobosan hukum dalam memecahkan, memberi arahan, dan melegitimasi terhadap tradisi yang bersifat lokal, konsual dan perkembangan sub

\footnotetext{
20 Daud Ali, Hukum Islam, hlm. 280..

19 Ditbinbapera, Kompilasi Hukum Islam, Pasal 209 Ayat 2, hlm. 57.
} 
kultur atau konvensi ketatanegaraan, dan hal itu merupakan hikmah dari asas umum pembinaan hukum Islâm.

b. Dalam kaitannya dengan kemaslahatan, syarî̀ah selalu memelihara tradisi dan transaksi masyarakat yang berlaku, selama tidak bertentangan dengan ajaran pokok agama dan tidak menimbulkan bahaya. ${ }^{21}$

Pemberian wasiat wâjibah sebagaimana ketentuan konpilasi hukum Islâm pasal 209 ayat 2 tersebut, merupakan pemeliharaan tradisi dan transaksi masyarakat, tidak bertentangan dengan ajaran pokok agama dan tidak meninggalkan bahaya dan bahkan sebaliknya, mendatangkan

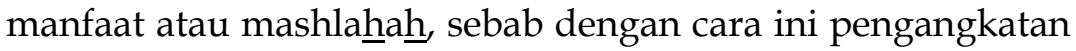
anak yang benar dapat menyelamatkannya dari ke sengsaraan dan hidup terlantar. Langkah ini menjadi sangat tepat, karena bisa membawa anak angkat bermotif sosial keagamaan lebih dekat kepada kemaslahatan dan lebih jauh dari pada kerusakan, meskipun tidak digariskan oleh Rasûlullâh dan tidak diturunkan oleh wahyu.

\section{Penutup}

Dalam akhir tulisan ini dapat disimpulkan beberapa hal yang akan memudahkan penangkapan uraian yang agak panjang di depan. Kesimpulannya adalah bahwa anak angkat tidak bisa termasuk kepada ahli waris sehingga ia tidak berhak mendapat harta warisan. Untuk mengalihkan atau memindahkan harta warisan dari bapak angkat kepada anak angkat terdapat beberapa pilhan alternatif, yaitu: Pertama, hibah dari orang tua angkat. Kedua, wasiat yang dilakukan oleh orang tua angkat kepada anak angkat terutama yang tidak memiliki ahli waris. Ketiga, wasiat wâjibah sebagai sebuah peralihan hak yang dianjurkan oleh hukum Islâm dari seseorang kepada pihak lain yang bukan ahli warisnya atau ia termasuk ahli waris, tetapi ia ter-mahjûb oleh ahli waris yang lain. Wallâh a'lâm bi al-shawâb

\footnotetext{
21 Syaichul Hadi Permono, Dinamisasi Hukum Islâm dalam Menjawab Tantangan Era Globalisasi (Surabaya: Demak Press, 2002), hlm. 18.
} 
Abd. Ghoffar

\section{Daftar Pustaka}

Abdillâh, Abû. Shahîh al-Bukhârî, Juz 7. Beirut: Dâr al- Mathabi alSya'bî, t.th.

Ali, Muhammad Daud. Hukum Islam; Pengantar Ilmu Hukum dan Tata Hukum Islam di Indonesia. Jakarta: Raja Grafindo Persada,t.th.

Alûsî, Al-. Tafsîr Rûh al-Ma'âni , Juz 21. Beirut : Dâr al-Fikr, t.th

Departemen Agama RI., Al-Qur'an dan Terjemahnya. Jakarta: Proyek Pengadaan Kitab Suci al-Qur'an, 1977/1978.

Ditbinbapera, Kompilasi Hukum Islam. Jakarta: Ditbinbapera, 1991/1992.

Khin, Musthofa al- et.el., Al-figh al-Manhaji. Juz III, Damaskus: Dâr al Fikr, t.th.

Nawâwî, Al-. Al-Muhadzab. Juz 1 Beirut: Dâr al-Fikr, t.th.

Permono, Syaichul Hadi. Dinamisasi Hukum Islâm dalam Menjawab Tantangan Era Globalisas.i Surabaya: Demak Press, 2002.

Sâyis, Alî al-. Tafsîr Âyât al-Ahkkâm, Juz 4. Damaskus: Dâr al Fikr, t.th.

Shabûnî, Muhammad Alî al-. Tafsîr Âyât al-Ahkâm, Juz 2. Makkah : Dâr al-Fikr, t.th.

Syaltût, Mahmûd. al-Fatawâ. Damaskus: Dâr al-Qolam, t.th.

Syawkânî, Al-. Irsyâd al-Fuhûl, Juz 6. Beirut: Dâr al-Fikr, t.th.

Zuhaylî, Wahbah al-. Al-Figh al-Islâmî wa Adilatuhu, Juz 8. Damaskus: Dâr al-Fikr, 1989. 